\title{
PERBANDINGAN EFEK ANALGESIK PERASAN RIMPANG JAHE MERAH (Zingiber officinale var. rubrum Thelaide) DENGAN ASPIRIN DOSIS TERAPI PADA MENCIT (Mus musculus)
}

\author{
${ }^{1}$ Natalia Christine Mantiri \\ ${ }^{2}$ Henoch Awaloei \\ ${ }^{2}$ Jimmy Posangi \\ ${ }^{1}$ Kandidat Skripsi Universitas Sam Ratulangi \\ ${ }^{2}$ Bagian Farmakologi dan Terapi Universitas Sam Ratulangi Manado \\ Email: nataliachristine@live.com
}

\begin{abstract}
This research purpose to compare analgesic effect from red ginger rhizome juice to therapeutic doses of aspirin. This research is an experimental research with treatment to aspirin group and red ginger rhizome juice mice as trial animals divided into 4 groups, each group contain of 3 mice. Four treatment groups contain of the group aspirin 0,4/20 gr BB and the group of red ginger rhizome juice in 3 different doses which are $4 \mathrm{mg} / 20 \mathrm{gr} \mathrm{BB}, 8 \mathrm{mg} / 20 \mathrm{gr} \mathrm{BB}$, $16 \mathrm{mg} / 20 \mathrm{gr} \mathrm{BB}$. Analgesic effect we could saw with counting mice responses likes jump and lick to decrease or release the pain. Before the treatment, all of mice fasted around 11 hours, and then gave the treatment. Studied of mice's responses on the water bath take for 1 minute, on the 0 minute before treatment, and on the 30,60, 90, 120 minutes after the treatment. Statistical analysis used ANOVA test and continued with LSD (Least Significance Different). Result from ANOVA test showed that there is real difference between the treatment groups. LSD test showed there are no real difference between the treatment group of aspirin to the treatment group of red ginger rhizome juice dose I. On the treatment group of red ginger rhizome juice dose II and dose III there is real difference to the treatment group of aspirin. The treatment group of red ginger rhizome juice dose II to dose III there is no real difference.
\end{abstract}

Keywords: Analgesic, Aspirin, Red Ginger (Zingiber officinale var. rubrum Thelaide).

\begin{abstract}
Abstrak: Penelitian ini bertujuan untuk melihat perbandingan efek analgesik perasan rimpang jahe merah dengan aspirin dosis terapi. Penelitian ini merupakan penelitian eksperimental dengan kelompok perlakuan aspirin dan perasan rimpang jahe merah. Mencit sebagai hewan coba sebanyak 12 ekor dibagi 4 kelompok masing-masing terdiri dari 3 ekor mencit. Empat kelompok perlakuan yaitu kelompok diberi aspirin 0,4 mg/20gr BB dan kelompok diberi perasan rimpang jahe merah dengan 3 dosis berbeda yaitu $4 \mathrm{mg} / 20 \mathrm{gr} \mathrm{BB}, 8 \mathrm{mg} / 20 \mathrm{gr} \mathrm{BB}, 16$ $\mathrm{mg} / 20 \mathrm{gr}$ BB. Efek analgesik dilihat dengan menghitung respon mencit berupa lompatan dan jilatan saat diberi rangsangan panas dengan suhu $55^{\circ} \mathrm{C}$. Sebelum perlakuan semua mencit dipuasakan kurang lebih 11 jam, kemudian diberi perlakuan. Pengamatan respon mencit pada water bath dilakukan selama 1 menit, pada menit ke-0 sebelum perlakuan, dan pada menit ke-30, 60, 90, 120 setelah perlakuan. Data dianalisis dengan uji ANOVA dan dilanjutkan dengan uji LSD (Least Significance Different). Hasil analisis statistik dengan uji ANOVA menunjukkan ada perbedaan nyata antar kelompok perlakuan. Uji LSD menunjukkan tidak terdapat perbedaan nyata pada kelompok perlakuan aspirin terhadap kelompok perlakuan perasan rimpang jahe merah dosis I. Pada kelompok perlakuan perasan jahe merah dosis II dan III terdapat perbedaan nyata terhadap kelompok perlakuan aspirin. Kelompok perlakuan perasan rimpang jahe merah dosis II terhadap dosis III tidak terdapat perbedaan nyata.
\end{abstract}

Kata Kunci: Analgesik, Aspirin, Jahe Merah (Zingiber officinale var. rubrum Thelaide). 
Kehidupan masyarakat dunia saat ini cenderung kembali ke alam termasuk di bidang obat-obatan untuk menyembuhkan suatu penyakit. Masyarakat beralih ke tumbuhan obat karena memiliki efek samping yang relatif lebih sedikit dari pada obat modern bila digunakan dengan benar dan efektif. ${ }^{1}$

WHO merekomendasikan penggunaan obat tradisional termasuk herbal pencegahan dan pengobatan penyakit terutama penyakit kronis, degeneratif dan kanker. ${ }^{2}$ Berdasarkan hasil penelitian para ahli baik dalam maupun luar negeri, tanaman jahe memiliki efek farmakologis yang berkhasiat sebagai obat bagi tubuh manusia. Menurut penelitian yang pernah dilakukan oleh Grzanna, ${ }^{3}$ efek antiinflamasi dari tanaman jahe telah diketahui berabad-abad yang lalu. Dalam 25 tahun terakhir, penelitian laboratorium menemukan bukti ilmiah bahwa tanaman jahe mengandung unsur-unsur anti inflamasi. Rimpang jahe memiliki kandungan minyak atsiri dan oleoresin yang ampuh menyembuhkan berbagai penyakit. ${ }^{4}$ Secara empiris tanaman jahe biasanya digunakan masyarakat sebagai obat masuk angin, gangguan pencernaaan, analgesik, antipiretik, anti-inflamasi, obat diare, dan dapat meningkatkan daya tahan tubuh. Tanaman jahe juga mempunyai senyawa aktif non volatil fenol seperti gingerol, shogaol, dan gingeron yang cukup tinggi dan berperan sebagai antioksidan alami bahkan melebihi vitamin E. ${ }^{5,6}$

Nyeri merupakan salah satu gejala penyakit yang sering dirasakan masyarakat pada umumnya. ${ }^{7}$ Untuk menghilangkan rasa nyeri ini, masyarakat memilih membeli obat-obat analgesik yang dijual dengan bebas. Aspirin merupakan obat golongan analgesik nonopioid yang paling sering dipakai untuk mengobati nyeri ringan sampai sedang. Mekanisme kerjanya terletak di perifer, berupa penghambatan biosintesis prostaglandin. Aspirin memiliki beberapa efek samping diantaranya induksi tukak peptik, anemia karena perdarahan saluran cerna. $^{8}$

Berdasarkan penelitian yang dilakukan tentang manfaat rimpang jahe merah dan efek samping yang bisa ditimbulkan oleh aspirin, maka penulis tertarik untuk meneliti efek kekuatan analgesik perasan rimpang jahe merah (Zingiber officinale var. rubrum Thelaide) dibandingkan dengan pemberian aspirin dosis terapi pada mencit.

\section{METODE PENELITIAN}

Penelitian ini merupakan penelitian eksperimental dilakukan dari bulan September 2012-Januari 2013. Penelitian ini dilakukan di Laboratorium Farmakologi dan Terapi Fakultas Kedokteran Universitas Sam Ratulangi Manado. Variabel Penelitian berupa perasan rimpang jahe merah (Zingiber officinale var. rubrum Thelaide), aspirin dan efek analgesik.

\section{Alat dan bahan}

Alat-alat yang digunakan yaitu kandang mencit, timbangan digital, kain penyaring, blender, water bath, stopwatch, NGT pediatric No. 3,5, disposibel injeksi $1 \mathrm{ml}, 10$ $\mathrm{ml}$, beaker glass yang disambungkan dengan karton, lumpang dan bahan yang digunakan yaitu perasan rimpang jahe merah, aspirin, dan aquadest.

\section{Prinsip penelitian}

Penelitian ini dilakukan dengan melihat respon mencit berupa melompat dan atau menjilat saat diberi rangsangan panas dengan suhu $55^{\circ} \mathrm{C}$. Respon mencit berupa lompatan dan atau jilatan ini merupakan reaksi nyeri yang ditimbulkan oleh rangsangan panas. Penilaian respon mencit diamati selama 1 menit setelah mencit diberi bahan uji berupa aspirin, dan perasan rimpang jahe merah.

\section{Penentuan dosis}

Aspirin diberikan sebanyak 0,4 mg/20gr BB mencit. Pada kelompok perlakuan perasan rimpang jahe merah diberikan dosis I 4 $\mathrm{mg} / 20 \mathrm{gr} \mathrm{BB}$, dosis II $8 \mathrm{mg} / 20 \mathrm{gr} \mathrm{BB}$, dosis III 16 mg/20gr BB.

\section{Cara kerja}

Ada beberapa hal yang perlu disiapkan 
dan dilakukan dalam penelitian ini, seperti pembuatan perasan rimpang jahe merah dan langkah pengujian efek analgesik

\section{Pembuatan perasan rimpang jahe merah}

Rimpang jahe merah yang diambil dibersihkan untuk menghilangkan kotoran yang menempel pada jahe merah. Rimpang jahe merah kemudian dikupas bagian kulit, dan dihaluskan menggunakan blender. Rimpang jahe merah yang sudah dihaluskan kemudian diperas dengan kain bersih untuk memperoleh hasil akhir yang akan digunakan.

\section{Langkah penelitian}

Mencit dipuasakan kurang lebih 11 jam sebelum diberi perlakuan, kemudian ditimbang berat badan setiap mencit dan dikelompokkan dalam 4 kelompok terdiri dari 3 ekor mencit. Mencit kemudian diletakkan di atas water bath dengan suhu $55^{0} \mathrm{C}$ sebelum diberi perlakuan kemudian amati respon mencit berupa lompatan dan jilatan selama 1 menit. Masing-masing mencit diberi perlakuan kemudian dihitung kembali respon mencit pada menit ke-30, 60, 90, dan 120 setelah diberi perlakuan.

Semua data yang diperoleh kemudian dilakukan penilaian kumulatif terhadap rangsangan nyeri. Penyajian dan pengolahan data menggunakan tabel, grafik, dan uji statistik dengan uji ANOVA.

\section{HASIL PENELITIAN}

Data di bawah ini merupakan data hasil pengamatan terhadap keempat kelompok perlakuan.

Pada Tabel 1 dibawah dapat dilihat efek analgesik berupa respon mencit pada kelompok pertama yang diberi aspirin yaitu rata-rata 45 kali sebelum perlakuan. Pada menit ke-30 setelah perlakuan dengan diberi aspirin menjadi 46,3 kali, pada menit ke-60 menjadi 30 kali, pada menit ke-90 menjadi 34,3 kali, dan pada menit ke-120 menjadi 35 kali.

Tabel 1. Hasil pengamatan respon mencit kelompok perlakuan yang diberi aspirin

\begin{tabular}{|c|c|c|c|c|c|c|c|c|c|c|c|c|c|c|c|}
\hline \multirow{3}{*}{ Mencit } & \multirow{2}{*}{\multicolumn{3}{|c|}{$\begin{array}{l}\text { Sebelum } \\
\text { perlakuan } \\
\text { (kali) }\end{array}$}} & \multicolumn{12}{|c|}{ Setelah Perlakuan } \\
\hline & & & & \multicolumn{3}{|c|}{30 ' } & \multicolumn{3}{|c|}{ 60' } & \multicolumn{3}{|c|}{ 90' } & \multicolumn{3}{|c|}{120} \\
\hline & $\mathbf{J}$ & $\mathbf{L}$ & $\mathbf{T}$ & $\mathbf{J}$ & $\mathbf{L}$ & $\mathbf{T}$ & $\mathbf{J}$ & $\mathbf{L}$ & $\mathbf{T}$ & $\mathbf{J}$ & $\mathbf{L}$ & $\mathbf{T}$ & $\mathbf{J}$ & $\mathbf{L}$ & $\mathbf{T}$ \\
\hline I & 35 & 4 & 39 & 37 & 2 & 39 & 34 & 2 & 36 & 31 & 1 & 32 & 37 & 1 & 38 \\
\hline II & 32 & 3 & 35 & 50 & - & 50 & 31 & - & 31 & 21 & - & 21 & 24 & - & 24 \\
\hline III & 61 & - & 61 & 50 & - & 50 & 23 & - & 23 & 50 & - & 50 & 43 & - & 43 \\
\hline Jumlah & \multicolumn{3}{|c|}{135} & \multicolumn{3}{|c|}{139} & \multicolumn{3}{|c|}{90} & \multicolumn{3}{|c|}{103} & \multicolumn{3}{|c|}{105} \\
\hline Rata-rata & \multicolumn{3}{|c|}{45} & \multicolumn{3}{|c|}{46,3} & \multicolumn{3}{|c|}{30} & \multicolumn{3}{|c|}{34,3} & \multicolumn{3}{|c|}{35} \\
\hline
\end{tabular}

Tabel 2. Hasil pengamatan respon mencit kelompok perlakuan yang diberi perasan rimpang jahe merah dosis I

\begin{tabular}{|c|c|c|c|c|c|c|c|c|c|c|c|c|c|c|c|}
\hline \multirow{3}{*}{ Mencit } & \multirow{2}{*}{\multicolumn{3}{|c|}{$\begin{array}{l}\text { Sebelum } \\
\text { perlakuan } \\
\text { (kali) }\end{array}$}} & \multicolumn{12}{|c|}{ Setelah Perlakuan } \\
\hline & & & & \multicolumn{3}{|c|}{30 ' } & \multicolumn{3}{|c|}{60} & \multicolumn{3}{|c|}{ 90' } & \multicolumn{3}{|c|}{ 120' } \\
\hline & $\mathbf{J}$ & $\mathbf{L}$ & $\mathbf{T}$ & $\mathbf{J}$ & $\mathbf{L}$ & $\mathbf{T}$ & $\mathbf{J}$ & $\mathbf{L}$ & $\mathbf{T}$ & $\mathbf{J}$ & $\mathbf{L}$ & $\mathbf{T}$ & $\mathbf{J}$ & $\mathbf{L}$ & $\mathbf{T}$ \\
\hline I & 33 & - & 33 & 35 & - & 35 & 20 & - & 20 & 36 & - & 36 & 55 & - & 55 \\
\hline II & 41 & - & 41 & 50 & - & 50 & 40 & - & 40 & 21 & - & 21 & 20 & - & 20 \\
\hline III & 90 & - & 90 & 24 & - & 24 & 38 & - & 38 & 47 & - & 47 & 32 & - & 32 \\
\hline Jumlah & \multicolumn{3}{|c|}{164} & \multicolumn{3}{|c|}{109} & \multicolumn{3}{|c|}{98} & \multicolumn{3}{|c|}{104} & \multicolumn{3}{|c|}{107} \\
\hline Rata-rata & \multicolumn{3}{|c|}{54,6} & \multicolumn{3}{|c|}{36.3} & \multicolumn{3}{|c|}{33.6} & \multicolumn{3}{|c|}{34,6} & \multicolumn{3}{|c|}{35,6} \\
\hline
\end{tabular}

Keterangan : $\mathrm{J}=$ Jilat, $\mathrm{L}=$ Lompat, $\mathrm{T}=$ Total 
Pada Tabel 2 di atas dapat dilihat efek analgesik dari kelompok perlakuan perasan rimpang jahe merah dosis I yaitu rata-rata 54,6 kali sebelum perlakuan. Pada menit ke30 setelah perlakuan menjadi 36,3 kali. Pada menit ke-60 menjadi 33,6 kali. Pada menit ke-90 menjadi 34,6 kali, dan pada menit ke120 menjadi 35,6 kali.

Pada Tabel 3 dapat dilihat efek analgesik dari kelompok perlakuan perasan rimpang jahe merah dosis II yaitu rata-rata 32,3 kali sebelum perlakuan. Pada menit ke30 setelah perlakuan menjadi 19 kali. Pada menit ke-60 menjadi 21,3 kali. Pada menit ke-90 menjadi 30,3 kali, dan pada menit ke120 menjadi 29,6 kali.

Pada Tabel 4 dibawah dapat dilihat efek analgesik dari kelompok perlakuan perasan rimpang jahe merah dosis III yaitu rata-rata
35,3 kali sebelum perlakuan. Pada menit ke30 setelah perlakuan menjadi 22,3 kali. Pada menit ke-60 menjadi 27,6 kali. Pada menit ke-90 menjadi 31,6 kali, dan pada menit ke120 menjadi 29,6 kali.

Berdasarkan data yang didapat, dilakukan uji data statistik dengan uji ANOVA terhadap kelompok kontrol dan kelompok perlakuan dan didapatkan hasil yang bermakna dengan nilai $\mathrm{p}=0,023(\mathrm{p}<\alpha)$, Hubungan keseluruhan variabel dikatakan signifikan atau bermakna jika $p<\alpha(\alpha=0,05)$, dan berdasarkan hasil uji LSD (Least Significant Difference) terdapat perbedaan yang signifikan juga tidak signifikan antara kelompok perlakuan yang diberi aspirin dan kelompok perlakuan perasan rimpang jahe merah.

Tabel 3. Hasil pengamatan respon mencit kelompok perlakuan yang diberi perasan rimpang jahe merah dosis II

\begin{tabular}{|c|c|c|c|c|c|c|c|c|c|c|c|c|c|c|c|}
\hline \multirow{3}{*}{ Mencit } & \multirow{2}{*}{\multicolumn{3}{|c|}{$\begin{array}{l}\text { Sebelum } \\
\text { perlakuan } \\
\text { (kali) }\end{array}$}} & \multicolumn{12}{|c|}{ Setelah Perlakuan } \\
\hline & & & & \multicolumn{3}{|c|}{$30^{\prime}$} & \multicolumn{3}{|c|}{$60^{\prime}$} & \multicolumn{3}{|c|}{ 90' } & \multicolumn{3}{|c|}{ 120' } \\
\hline & $\mathbf{J}$ & $\mathbf{L}$ & $\mathbf{T}$ & $\mathbf{J}$ & $\mathbf{L}$ & $\mathbf{T}$ & $\mathbf{J}$ & $\mathbf{L}$ & $\mathbf{T}$ & $\mathbf{J}$ & $\mathbf{L}$ & $\mathbf{T}$ & $\mathbf{J}$ & $\mathbf{L}$ & $\mathbf{T}$ \\
\hline I & 13 & 18 & 31 & - & 5 & 5 & - & 30 & 30 & 2 & 27 & 29 & 19 & - & 19 \\
\hline II & 13 & 14 & 27 & 11 & 12 & 23 & 8 & 11 & 19 & 7 & 16 & 23 & 24 & 1 & 25 \\
\hline III & - & 39 & 39 & - & 29 & 29 & 2 & 13 & 15 & 39 & - & 39 & 45 & - & 45 \\
\hline Jumlah & \multicolumn{3}{|c|}{97} & \multicolumn{3}{|c|}{57} & \multicolumn{3}{|c|}{64} & \multicolumn{3}{|c|}{91} & \multicolumn{3}{|c|}{89} \\
\hline Rata-rata & \multicolumn{3}{|c|}{32,3} & \multicolumn{3}{|c|}{19} & \multicolumn{3}{|c|}{21,3} & \multicolumn{3}{|c|}{30,3} & \multicolumn{3}{|c|}{29,6} \\
\hline
\end{tabular}

Keterangan : $\mathrm{J}=$ Jilat, $\mathrm{L}=$ Lompat, $\mathrm{T}=$ Total

Tabel 4. Hasil pengamatan respon mencit kelompok perlakuan yang diberi perasan rimpang jahe merah dosis III

\begin{tabular}{|c|c|c|c|c|c|c|c|c|c|c|c|c|c|c|c|}
\hline \multirow{3}{*}{ Mencit } & \multirow{2}{*}{\multicolumn{3}{|c|}{$\begin{array}{l}\text { Sebelum } \\
\text { perlakuan } \\
\text { (kali) }\end{array}$}} & \multicolumn{12}{|c|}{ Setelah Perlakuan } \\
\hline & & & & \multicolumn{3}{|c|}{30 ' } & \multicolumn{3}{|c|}{60 ' } & \multicolumn{3}{|c|}{90 ' } & \multicolumn{3}{|c|}{120} \\
\hline & $\mathbf{J}$ & $\mathbf{L}$ & $\mathbf{T}$ & $\mathbf{J}$ & $\mathbf{L}$ & $\mathbf{T}$ & $\mathbf{J}$ & $\mathbf{L}$ & $\mathbf{T}$ & $\mathbf{J}$ & $\mathbf{L}$ & $\mathbf{T}$ & $\mathbf{J}$ & $\mathbf{L}$ & $\mathbf{T}$ \\
\hline $\mathrm{I}$ & 21 & 7 & 28 & 8 & 6 & 14 & - & 16 & 16 & 9 & 10 & 19 & 2 & 8 & 10 \\
\hline II & - & 18 & 18 & - & 16 & 16 & 19 & 7 & 26 & 31 & - & 31 & 39 & - & 39 \\
\hline III & 60 & - & 60 & 37 & - & 37 & 41 & - & 41 & 45 & - & 45 & 40 & - & 40 \\
\hline Jumlah & \multicolumn{3}{|c|}{106} & \multicolumn{3}{|c|}{67} & \multicolumn{3}{|c|}{83} & \multicolumn{3}{|c|}{95} & \multicolumn{3}{|c|}{89} \\
\hline Rata-rata & \multicolumn{3}{|c|}{35,3} & \multicolumn{3}{|c|}{22,3} & \multicolumn{3}{|c|}{27,6} & \multicolumn{3}{|c|}{31,6} & \multicolumn{3}{|c|}{29,6} \\
\hline
\end{tabular}

Keterangan : $\mathrm{J}=$ Jilat, $\mathrm{L}=$ Lompat, $\mathrm{T}=$ Total 
Tabel 5. Hasil uji LSD (Least Significant Difference) rata-rata respon mencit kelompok perlakuan yang diberi aspirin dibandingkan dengan kelompok perlakuan perasan rimpang jahe merah.

P (Signifikan)

\begin{tabular}{lll}
\hline Aspirin & Jahe Merah dosis I & 0,852 \\
& Jahe Merah dosis II & 0,016 \\
& Jahe Merah dosis III & 0,058 \\
\hline Jahe Merah dosis I & Jahe Merah dosis II & 0,011 \\
& Jahe Merah dosis III & 0,040 \\
\hline Jahe Merah dosis II & Jahe Merah dosis III & 0,530 \\
\hline
\end{tabular}

Keterangan : $\alpha=0,05$

Kriteria pengujian yaitu terdapat perbedaan yang bermakna dari respon mencit antar pasangan kelompok yang diuji jika nilai $\mathrm{p}<\alpha$. Pada Tabel 5 menunjukkan secara statistik:

1. Tidak terdapat perbedaan yang bermakna antara kelompok perlakuan yang diberi aspirin terhadap kelompok perlakuan perasan rimpang jahe merah dosis I.

2. Terdapat perbedaan yang bermakna antara kelompok perlakuan yang diberi aspirin terhadap kelompok perlakuan perasan rimpang jahe merah dosis II dan dosis III.

3. Terdapat perbedaan yang bermakna antara kelompok perlakuan perasan rimpang jahe merah dosis I terhadap dosis II dan dosis III.

4. Tidak terdapat perbedaan yang bermakna antara kelompok perlakuan perasan rimpang jahe merah dosis II dan dosis III.

\section{BAHASAN}

Penelitian yang dilakukan merupakan penelitian eksperimental dengan menggunakan hewan coba berupa mencit (Mus musculus) yang diberi perlakuan yaitu aspirin dan perasan rimpang jahe merah. Penelitian ini bertujuan untuk menilai adanya efek analgesik dari pemberian perasan rimpang jahe merah dibandingkan dengan aspirin, dan melihat efektivitas perasan rimpang jahe merah dalam menurunkan rasa nyeri. Pengujian efek analgesik menggunakan metode hot plate atau rangsangan panas. Efek analgesik dinilai dari respon mencit berupa lompatan dan jilatan sebagai reaksi dari mencit untuk menghilangkan rasa nyeri, dan jika jumlah lompatan dan jilatan semakin sedikit berarti nyeri yang dirasakan semakin berkurang atau efek analgesik pada mencit yang diberi perlakuan semakin kuat. Rasa nyeri dapat timbul akibat adanya stimulus pada reseptor nyeri yang bisa timbul dari rangsangan mekanis dan kimiawi atau panas. ${ }^{9}$ Mekanisme timbulnya rasa nyeri akibat adanya kerusakan jaringan sehingga fosfolipid membran sel mengalami perubahan menjadi asam arakidonat yang menyebabkan terbentuknya mediator kimiawi seperti prostaglandin. Prostaglandin ini dapat meningkatkan sensitivitas reseptor nosiseptor sehingga menimbulkan rasa nyeri. Pembentukan prostaglandin dapat dihambat dengan penggunaan obat-obat yang bekerja dengan cara menghambat enzim siklooksigenase.,

Berdasarkan hasil uji ANOVA (Analysis of Variance) didapatkan adanya perbedaan respon mencit yang bermakna antar kelompok perlakuan dengan nilai $\mathrm{p}<0,05$ (signifikan). Hasil uji dengan menggunakan LSD (Least Significant Difference) menunjukkan hasil yang tidak signifikan dari kelompok perlakuan yang diberi perasan rimpang jahe merah terhadap kelompok perlakuan yang diberi aspirin. Berdasarkan hasil uji tersebut dapat dikatakan bahwa perasan rimpang jahe merah dosis I 4mg/20gr BB memiliki efek analgesik yang sebanding dengan aspirin 0,4 mg/20gr BB. Pada kelompok perlakuan yang diberi aspirin terlihat respon mencit menurun pada menit ke-60, sedangkan pada kelompok yang diberi perasan rimpang jahe 
merah baik dosis I, II dan III terlihat penurunan respon mencit pada menit ke-30.

Kelompok perlakuan yang diberi aspirin menunjukkan adanya perbedaan yang bermakna terhadap kelompok perlakuan perasan rimpang jahe merah dosis II dan III, hal ini berarti efek analgesik yang ditimbulkan oleh perasan rimpang jahe merah dosis II $8 \mathrm{mg} / 20 \mathrm{gr}$ BB dan dosis III $16 \mathrm{mg} / 20 \mathrm{gr} \mathrm{BB}$ lebih kuat dibanding dengan aspirin dosis $0,4 \mathrm{mg} / 20 \mathrm{gr} \mathrm{BB}$. Pada dosis II dan dosis III tidak terdapat perbedaan yang bermakna satu sama lain. Berdasarkan uji ini terlihat efek maksimal yang ditimbulkan oleh perasan rimpang jahe merah yaitu pada dosis II 8 mg/20gr BB.

Efek analgesik perasan rimpang jahe merah berhubungan dengan unsur-unsur yang terkandung dalam jahe merah. Senyawa-senyawa gingerol, shogaol, zingerone, diarylheptanoids dan derivatnya terutama paradol diketahui dapat menghambat enzim siklooksigenase sehingga terjadi penurunan pembentukan atau biosintesis dari prostaglandin yang menyebabkan berkurangnya rasa nyeri. ${ }^{10,11,12}$

\section{SIMPULAN}

Dari hasil penelitian yang dilakukan, maka dapat disimpulkan bahwa perasan rimpang jahe merah dosis $\mathrm{I} 4 \mathrm{mg} / 20 \mathrm{gr} \mathrm{BB}$ memiliki efek analgesik sebanding dengan aspirin dosis $0,4 \mathrm{mg} / 20$ gr BB. Perasan rimpang jahe merah dosis II $8 \mathrm{mg} / 20 \mathrm{gr} \mathrm{BB}$ dan dosis III 16 mg/20 gr BB memiliki efek analgesik yang lebih kuat dibanding dengan aspirin dosis $0,4 \mathrm{mg} / 20$ gr BB. Efek maksimal dari perasan rimpang jahe merah yaitu pada dosis II $8 \mathrm{mg} / 20 \mathrm{gr}$ BB. Masa kerja efek analgesik perasan rimpang jahe merah lebih cepat yaitu pada menit ke-30 dibanding dengan aspirin yaitu pada menit ke-60.

\section{DAFTAR PUSTAKA}

1. Sangi $M$, Runtuwene $M$, Simbala $H$, Makang V. Analisis Fitokimia Tumbuhan Obat di Kabupaten Minahasa Utara. Ejournal Unsrat. 2008;1:47-53.
2. Sari LO. Pemanfaatan Obat Tradisional dengan Pertimbangan Manfaat dan Keamanannya. Majalah Ilmu Kefarmasian. 2006;3:01-07.

3. Grzanna R, Lindmark L, Frondoza CG. Ginger an Herbal Medicinal Product with Broad Anti-inflammatory Action. J Med Food. 2005;8:125-32.

4. Daryono ED. Oleoresin dari Jahe Menggunakan Proses Ekstraksi dari Pelarut Etanol. E-journal UPN. 2011;6:1-5.

5. Winarti C, Nurdjanah N. Peluang Tanaman Rempah dan Obat sebagai Sumber Pangan Fungsional. Jurnal Litbang Pertanian. 2005;24:49.

6. Setiyo Y, Tika IW, Sumiyati. Aplikasi Kompos sebagai Pupuk Organik untuk Meningkatkan Kandungan Fenol pada Tanaman Jahe Merah. Agrotekno. 2009;15:61-65.

7. Purba JS. Nyeri dan Sistem Imun: Sejauh Mana Keterkaitannya. Medicinus Journal. 2009;22:71-73.

8. Wilmana PF, Gan S. Analgesik-antipiretik, Analgesik Anti-inflamasi Nonsteroid, dan Obat Gangguan Sendi lainnya. Dalam: Gunawan GS, Nafrialdi RS, Elysabeth, editors. Farmakologi dan Terapi. Edisi 5. Jakarta: Balai Penerbit FKUI; 2009. h. 230-6.

9. Payan DG, Katzung BG. Nonsteroidal Anti-inflammatory Drugs, Diseasemodifying Antirheumatic Drugs, Nonopioid Analgesics, and Drugs Used in Gout. In: Katzung BG, Masters SB, Trevor AJ, editors. Basic and Clinical Pharmacology $\left(11^{\text {th }}\right.$ Ed). Stamford: Appleton dan Lange, 2009; p.806-24.

10. Black CD, Herring MP, Hurley DJ, O’Connor PJ. Ginger (Zingiber officinale) Reduces Muscle Pain Caused by Eccentric Exercise. The Journal of Pain. 2010;11:894903.

11. Haghighi M, Khalvat A, Toliat T, Jallaei S. Comparing The Effects of Ginger (Zingiber officinale) Extract and Ibuprofen on Patients with Osteoasthritis. Arch Iranian Med. 2005;8:267-271.

12. Ali BH, Blunden G, Tanira MO, Nemmar A. Some Phytochemical Pharmacological and Toxicological Properties of Ginger (Zingiber officinale Roscoe): A Review of Recent Research. Elsevier Food and Chemical Toxicology. 2008;46:409-20. 